\title{
História
}

\section{Análise de Produção Científica}

Geraldina Porto Witter UMC / PUC-Campinas

\begin{abstract}
As expressões análise da produção científica, metaciência, meta-análise hoje são de uso corrente e contam com muitos trabalhos publicados nas diversas ciências, inclusive na Psicologia, no exterior e no Brasil. Sua história é longa mas esparsa e com grandes interrupções. Nos anos sessenta apenas se esboçava mais sistematicamente esse esforço de análise do conhecimento científico no exterior. No Brasil também começou a surgir preocupação neste sentido.

Em 1965, um grupo de pioneiros na área apresenta na 17a Reunião Anual da Sociedade Brasileira para o Progresso da Ciência (SBPC), realizada em Belo Horizonte, uma análise de produção com o título Análise do Conteúdo da Psicologia Educacional. Assinam o trabalho Arrigo Leonardo Angelini, Samuel Pfromm Netto e Nelson Rosamilha. É um trabalho pioneiro não só no Brasil como internacionalmente. Os autores são personagens centrais da história da Psicologia no Brasil, o último deles faleceu muito cedo e nos seus poucos anos produziu trabalhos de mérito. Angelini teve papel de destaque na criação da profissão, sua legalização e na constituição do 1 Conselho Federal e dos primeiros Regionais, sem falar em sua vasta produção científica. Pfromm Netto está entre os primeiros a se destacarem por sua produção, pela formação de novas
\end{abstract}

gerações e pelo profundo conhecimento de história da Psicologia especialmente da nacional.

Nos anos sessenta mais do que hoje, muitos trabalhos eram apresentados em Congressos e eventos similares mas não chegavam à publicação. Este foi $o$ destino da meta-análise produzida por Angelini, Pfromm Netto e Rosamilha.

O texto ainda tem muito a dizer além de ser um marco histórico. Uma réplica do estudo seria de grande utilidade e permitiria uma análise comparativa muito útil. Certamente, hoje o trabalho seria muito menos árduo já que o computador oferece uma ajuda que acelera o processo de coleta e de análise de dados.

Neste presente número de Psicologia Escolar e Educacional está sendo publicado, na íntegra, tal qual foi apresentado na reunião da SBPC o texto aqui mencionado.

É uma honra para o periódico poder dar maior difusão e assegurar um melhor registro histórico da pesquisa citada. Manteve-se o formato original do documento, conforme foi divulgado na ocasião. Desta forma o mesmo pode ser útil para os que se interessam por história, discurso científico, produção científica e Psicologia Escolar. 